\title{
MODEL EVALUASI REFLEKTIF KURIKULUM PENDIDIKAN BAHASA INGGRIS DALAM PENGEMBANGAN KARAKTER BANGSA
}

\author{
${ }^{1)}$ Monika Gultom, ${ }^{2)}$ Sumarno, ${ }^{3)}$ Suwarsib Madya, \\ ${ }^{11}$ Universitas Cenderawasih Jayapura, ${ }^{2,3)}$ Universitas Negeri Yogyakarta \\ ${ }^{1)}$ monikagultom27@gmail.com, ${ }^{3)}$ suwarsihm@yahoo.com
}

\begin{abstract}
Abstrak
Penelitian ini bertujuan untuk mengembangkan model evaluasi reflektif kurikulum rumpun mata kuliah keahlian pendidikan bahasa Inggris untuk memotret penuangan nilai-nilai karakter bangsa di dalam kelas. Penelitian pengembangan ini menggunakan pendekatan campuran dalam lima tahap, yaitu studi awal, pendefinisian, perancangan, peragaan, dan pengembangan. Penetapan konstuk dilakukan melalui penilaian pakar, dengan subyek penelitian dosen dan mahasiswa di Program Studi Pendidikan Bahasa Inggris yang ada di DIY. Penentuan koefisien reliabilitas instrumen evaluasi menggunakan program SmartPLS Versi 2.0.M3 dan uji kelayakan model dengan program GeSCA. Hasil penelitian menyimpulkan: (1) model evaluasi yang dikembangkan didukung oleh lima instrumen evaluasi; (2) validitas, reliabilitas, dan kepraktisan instrumen evaluasi telah teruji melalui kegiatan FGD, teknik Delphi, dan analisis faktor konfirmatori non-parametrik; (3) koefisien reliabilitas komposit kelima instrumen adalah sebesar 0,93 ; 0,$91 ; 0,95 ; 0,95$; dan 0,86 ; (4) hasil uji kelayakan model menunjukkan model didukung oleh data ditunjukkan oleh nilai GFI 0,99 dan SRMR 0,06; 5) Pedoman penggunaan model dalam bentuk panduan evaluasi.
\end{abstract}

Kata kunci: pengembangan model evaluasi kurikulum, karakter bangsa

\section{MODEL OF REFLECTIVE CURRICULUM EVALUATION OF ENGLISH LANGUAGE EDUCATION IN DEVELOPING NATIONAL CHARACTER}

\author{
${ }^{1)}$ Monika Gultom, ${ }^{2)}$ Sumarno, ${ }^{3)}$ Suwarsib Madya \\ ${ }^{1)}$ Universitas Cenderawasih Jayapura, ${ }^{2,3)}$ Universitas Negeri Yogyakarta \\ ${ }^{1)}$ monikagultom27@gmail.com, ${ }^{3)}$ suwarsihm@yahoo.com
}

\begin{abstract}
This study aimed to develop a model of reflective curriculum evaluation at the English Education Study Program that portrayed the delivery of the values of national character in the classroom. This development study used mixed approach carried out in five phases: initial study, defining, designing, demonstrating, and developing. The constructs of instruments were developed based on expert judgments; the subjects were lecturers and students of English Language Education Study Program in four universities in Yogyakarta Special Territory. The composite reliability coefficient of the instruments was analyzed by SEM program of SmartPLS Version 2.0.M3 and test of fit model by GeSCA. The result of the study concluded: 1) the developed model evaluation was supported by five instruments of evaluation; 2) validity, reliability, and its implementation had been verified through FGD, Delphy techniques, and non-parametric confirmatory factor analysis; 3) the composite reliability coefficient of the five instruments was $0.93,0.91,0.95,0.95$, and 0.86 ; 4) the result of the test of fit model indicated that model was supported by the data with GFI 0.99 and SRMR 0.06; 5) The guidelines of using the developed model consisted of background, rational, components of assessment, guidelines, and application sample.
\end{abstract}

Keywords: developing model of curriculum evaluation, national character 


\section{Pendahuluan}

Kemajuan yang telah dicapai bangsa Indonesia dalam hal pembangunan fisik harus diimbangi dengan pembangunan nonfisik, termasuk di antaranya membangun karakter dan jati diri bangsa agar menjadi bangsa yang kokoh dan berpendirian teguh (Pemerintah RI, 2010: p.16). Pentingnya pembangunan karakter dan jati diri bangsa telah diamanatkan dalam UUD 1945, yaitu agar Pemerintah Indonesia mengusahakan dan menyelenggarakan satu sistem pendidikan nasional yang meningkatkan keimanan, ketakwaan kepada Tuhan Yang Maha Esa, dan akhlak mulia serta mencerdaskan kehidupan bangsa.

Amanat UUD 1945 ini berimplikasi pada pengembangan kurikulum untuk selalu mengacu pada standar nasional pendidikan untuk mewujudkan tujuan pendidikan nasional dengan memperhatikan beberapa aspek penting yang diantaranya adalah persatuan nasional dan nilai-nilai kebangsaan. Amanat UUD 1945 ini juga merupakan tantangan bagi pendidikan bahasa asing karena kental dengan pengenalan dan penguasaan terhadap sejarah, kebudayaan, karakteristik, pranata sosial budaya dan nilai-nilai yang dimiliki penutur asli bahasa target. Sementara, PP Nomor 19 Tahun 2005 mensyaratkan terpenuhinya standar isi dan proses terkait dengan pelaksanaan pembelajaran pada satuan pendidikan yang merupakan elemen penting dalam kurikulum sebagai pedoman penyelenggaraan pembelajaran bermuatan karakter bangsa.

Kontribusi besar pendidikan karakter dalam proses pembelajaran selaras dengan aspek filosofis, ideologis, normatif, historis, dan sosiokultural yang melatarbelakangi tercetusnya Kebijakan Nasional Pembangunan Karakter Bangsa tahun 2010-2025 (Pemerintah RI, 2010:, pp.1-3). Secara filosofis, pembangunan karakter bangsa bersifat esensial dalam proses berbangsa karena hanya bangsa yang memiliki karakter dan jati diri yang kuat yang akan bertahan; secara ideologis, pembangunan karakter merupakan pengejawantahan ideologi Pancasila dalam kehidupan berbangsa dan bernegara; secara normatif, pembangunan karakter bangsa merupakan wujud nyata langkah mencapai tujuan Negara; secara historis, pembangunan karakter bangsa merupakan dinamika inti proses kebangsaan yang terjadi tanpa henti dalam kurun sejarah; dan secara sosiokultural, pembangunan karakter bangsa merupakan suatu keharusan dari suatu bangsa yang multikultur.

UU Nomor 20 Tahun 2003 tentang Sistem Pendidikan Nasional dan Ketetapan Kementerian Pendidikan Nasional Badan Penelitian dan Pengembangan Pusat Kurikulum (2010, pp.9-10) mendudukkan pentingnya pendidikan di bidang budaya dan karakter bangsa. Nilai semangat kebangsaan dan cinta tanah air dideskripsikan sebagai cara berpikir, bertindak, dan berwawasan yang menempatkan kepentingan bangsa dan Negara di atas kepentingan diri dan kelompoknya, dan cara berpikir, bersikap, dan berbuat yang menunjukkan kesetiaan, kepedulian, dan penghargaan yang tinggi terhadap bahasa nasional, lingkungan fisik, sosial, budaya, ekonomi dan politik bangsa.

Meskipun banyak ahli menyatakan pentingnya membentuk karakter bangsa melalui pendidikan, misalnya $\mathrm{Ki}$ Hadjar Dewantara yang menekankan pentingnya membentuk karakter bangsa melalui pendidikan atau pengajaran yang selaras dengan kehidupan bangsa (Ki Hadjar Dewantara, 2004), dalam praktiknya belum sepenuhnya terlaksana. Beberapa penelitian menunjukkan banyak program pendidikan guru yang secara tidak sungguh-sungguh mempersiapkan calon guru untuk menjadi guru yang tidak hanya menguasai ilmu pengetahuan dan keterampilan mengajar tetapi juga bagaimana menjadi pendidik nilai-nilai moral (Narvaez \& Lapsley, 2006; Berkowitz \& Bier, 2004, p.72).

Terlebih lagi, beberapa penelitian lain menunjukkan bahwa kurikulum bidang pendidikan memberikan lebih sedikit pengajaran tentang aspek-aspek moral kepada mahasiswanya dibandingkan dengan kurikulum pada pembelajaran pada disiplin ilmu lainnya (Lampe, 1994; McNeel, 1994 dalam Leming, 2000, pp.421-2), padahal, kurikulum 
dengan penekanan pembelajaran bermuatan karakter terbukti memberikan kontribusi yang lebih besar ketimbang variabel lainnya. Dengan kata lain, muatan kurikulum menunjukkan kesiapan dan keseriusan suatu lembaga pendidikan dalam membentuk karakter bangsa peserta didik melalui pendidikan. Muatan kurikulum menunjukkan bagaimana dan seberapa jauh lembaga pendidikan mempersiapkan peserta didik memegang peranan penting pengembangan karakter (Bath, Smith, Stein \& Swann, 2004), terutama dalam menjawab tantangan zaman, perubahan kondisi, pergantian kebijakan, dan juga dalam merespon kebutuhan pasar lokal.

Sementara itu, belum banyak dilakukan evaluasi kurikulum tentang muatan nilai-nilai karakter bangsa dalam konteks pembelajaran, mengingat evaluasi kurikulum dalam konteks pembelajaran dapat membantu mengetahui apa yang sebenarnya terjadi di dalam kelas (Martone \& Sireci, 2009, p.1332). Sebagai faktor penentu, evaluasi terhadap kurikulum berarti merujuk pada apa yang sebenarnya terjadi di dalam kelas, termasuk perencanaan pembelajaran dan implementasi kurikulum di dalam kelas (Richards, 2001). Evaluasi kurikulum kebanyakan berpegang pada hasil pengukuran skor prestasi belajar siswa dalam menentukan keberhasilan suatu kurikulum, dengan asumsi yang dipegang adalah berdasarkan kepada efisiensi, efektivitas biaya, kemampuan siswa, dan rata-rata perolehan nilai siswa (Apple \& Beyer, 1983, p.425). Mengingat institusi pendidikan seperti sekolah atau universitas bukanlah suatu entitas yang terisolasi, atau terpisah dari masalah-masalah ekonomi, sosial, dan budaya, maka penelitian yang dilaporkan disini difokuskan pada pengembangan suatu model evaluasi kurikulum yang merefleksikan muatan karakter bangsa.

Berdasarkan penelitian prasurvei yang dilakukan pada awal tahun 2011 yang lalu, beberapa lembaga pendidikan bahasa Inggris di Provinsi DIY menunjukkan adanya komitmen pada pengembangan karakter dengan variasi model pendekatan pembel- ajaran yang beragam. Rancangan model evaluasi pada penelitian ini merupakan kombinasi dari model evaluasi CIPP (Worthen \& Sanders, 1984) dan kerangka Logic Model (Taylor-Powell, Jones \& Henert, 2003), dan dikembangkan untuk dapat melihat kekuatan dari masing-masing model pendekatan pembelajaran dalam Prodi pendidikan bahasa Inggris tersebut.

Pendidikan bahasa Inggris memiliki karakteristik yang sangat kental dengan pengenalan dan penguasaan akan sejarah, kebudayaan, karakteristik, pranata sosial budaya dan nilai-nilai yang dimiliki oleh penutur asli. Peluang dan tantangan yang dimiliki lembaga pendidikan bahasa Inggris ini dapat dijawab dengan adanya suatu alat evaluasi yang mampu meneropong dan mengontrol bagaimana penanaman nilai-nilai karakter bangsa dalam kerangka pengembangan pendidikan nilai budaya dan karakter bangsa dituangkan dalam pembelajaran bahasa Inggris tumbuh di dalam kesadaran peserta didik.

Lembaga pendidikan, dalam hal ini Prodi PBI, mengemban tugas dan tanggung jawab yang besar dalam menghasilkan calon guru yang tidak hanya memiliki intelektualitas yang tinggi, terlebih penting lagi memiliki karakter yang utuh dengan integritas yang tinggi dalam mendidik generasi penerus bangsa yang berkarakter. Calon guru yang dididik dengan penanaman nilainilai karakter bangsa tersebut merupakan ujung tombak pencapaian cita-cita luhur bangsa sehingga perlu dibekali dengan penghayatan dan kesadaran akan tugas dan fungsi utamanya sebagai pendidik.

Sebagai perwujudan cita-cita luhur bangsa Indonesia yang tercantum dalam Pembukaan UUD 1945, pengimplementasian pembangunan karakter bangsa dalam kurikulum dan pembelajaran di kelas perlu diberi dukungan sepenuhnya, terutama untuk menjawab tantangan arus globalisasi. Pendidikan bahasa Inggris memiliki potensi yang besar dalam mewujudkan cita-cita luhur bangsa melalui pembangunan karakter peserta didik yang utuh dan juga nasionalis yang tertuang dalam kurikulum. 
Kurikulum adalah rangkaian perencanaan pendidikan yang mencakup pengalaman seorang anak dalam lembaga pendidikan, keseluruhan pengalaman di kelas yang direncanakan dan diperankan dosen, keseluruhan pengalaman yang disediakan untuk mahasiswa sehingga mereka dapat memperoleh keterampilan dan pengetahuan dalam berbagai konteks pembelajaran (Ornstein \& Huskins, 2009, pp.10-11; Parkay \& Anctil, 2010, p.2; Marsh, 2009, p.7). Kurikulum dalam pembelajaran bahasa adalah rangkaian proses perancangan, perbaikan, pelaksanaan, dan evaluasi program pembelajaran bahasa (Richards, 2001, p.2). Dalam hal ini, kurikulum bersifat spesifik pada apa yang terjadi di dalam kelas dimana dosen dan mahasiswa menjadi kurikulum dari pembelajaran tersebut.

Kurikulum dalam pengertian di atas disebut dengan silabus dan dipahami sebagai spesifikasi dari isi dan urutan pembelajaran yang akan diajarkan, instrumen yang membantu pengembang silabus untuk mencapai kesesuaian antara apa yang dibutuhkan dan tujuan belajar peserta didik sebagai makhluk sosial dan sebagai individu, dan dengan semua kegiatan belajar yang terjadi di dalam kelas (Nunan, 2004, p.3). Dalam hal ini, proses penyusunan dan pengembangan kurikulum dalam pembelajaran bahasa adalah hasil olah pikir seorang pengembang kurikulum berdasarkan pemahamannya tentang pendidikan dan peserta didik yang akan menerima pembelajaran (Jackson, 1992, p.21), memegang peranan penting dalam menentukan penuangan muatan karakter bangsa dalam kurikulum pembelajaran yang diselenggarakannya.

Karakter bangsa adalah kualitas perilaku kolektif kebangsaan yang khas-baik yang tercermin dalam kesadaran, pemahaman, rasa, karsa, dan perilaku berbangsa dan bernegara sebagai hasil olah pikir, olah hati, olah rasa dan karsa, serta olah raga seseorang atau sekelompok orang (Pemerintah RI, 2010, p.7). Karakter bangsa dalam pandangan Anthropologi adalah tata nilai budaya dan keyakinan yang mengejewantah dalam kebudayaan masyarakat dan meman- carkan ciri-ciri khas keluar sehingga dapat ditanggapi oleh orang luar sebagai kepribadian masyarakat tersebut (Saifuddin \& Karim, 2008, p.8). Karakter bangsa sebagai nasionalisme adalah keyakinan dari suatu komunitas yang memiliki pengalaman yang berbeda tetapi disatukan dalam satu rezim politik (Meadow, 2008). Dengan demikian, karakter bangsa berarti suatu keyakinan yang terbentuk secara sosial, yang mempererat dan membentuk cara berkomunikasi suatu komunitas yang membentuk dan menghasilkan proposisi-proposisi dan hal-hal simbolis bersama yang menjadi identitas nasional komunitas tersebut.

Karakter bangsa sebagai identitas nasional dimaknai sebagai suatu komunitas masyarakat yang hidup dalam suatu wilayah/teritori ataupun dari luar wilayah/teritori suatu Negara, sebagai bagian dari anggota komunitas politik yang memiliki budaya dan ideologi yang sama dan juga kesamaan keturunan, etnik, ikatan persaudaraan, saling berbagi dalam hal budaya dan ikatanikatan sosial, meliputi semua hal yang secara hukum dimiliki seorang warga Negara diluar etnik atau budaya tertentu (Parmenter, 1999, p.455). Dalam pandangan ini, karakter bangsa adalah identitias nasional yang terbentuk tidak hanya berdasarkan batas-batas geografi maupun kategori-kategori etnik semata, tetapi lebih menitikberatkan pada ikatan saling memberi dan berbagi dalam hal budaya dan ikatan-ikatan sosial.

Dengan demikian, karakter bangsa sebagai identitas nasional dapat dipahami sebagai bentuk kesadaran atau sikap nasionalisme yang menyatukan suatu bangsa secara politik, kewilayahan, sejarah, dan ideologis. Meskipun batasan tentang nasionalisme ini memiliki pengaruh langsung terhadap kelaskelas pembelajaran bahasa asing, bahkan beberapa ahli berpendapat ideologi nasionalisme mengganggu keefektifan pembelajaran bahasa asing (Meadows, 2008,p.118), sekolah atau lembaga pendidikan mempunyai tanggung jawab membentuk moral masyarakat atau karakter kebangsaan yang sesuai dengan yang dikehendaki masyarakatnya (Sari \& Doğanay, 2009). Dalam hal ini, mo- 
ral masyarakat yang sesuai dengan kehendak masyarakatnya adalah nilai-nilai moral yang merupakan kepribadian bangsa tersebut.

Nilai-nilai Pancasila, sebagai kepribadian bangsa Indonesia, yang terkandung dalam ke-lima silanya merupakan cerminan kepribadian bangsa yaitu karakter keIndonesiaan yang merupakan jati diri bangsa yang telah ditetapkan dalam ketetapan MPR RI No. VII/MPR/1978 adalah karakter yang religius, manusiawi, bersatu, demokratis, dan adil (Winarno, 2010, p.10). Karakter bangsa Indonesia yang khas baik tercermin dalam kesadaran, pemahaman, rasa, karsa dan perilaku berbangsa dan bernegara berdasarkan nilai-nilai Pancasila, norma UUD 1945, prinsip Bbinneka Tunggal Ika, dan komitmen terhadap NKRI (Pemerintah RI, 2010, p.7).

Keempat pilar kebangsaan yang merupakan dasar nilai, norma, prinsip, dan komitmen hidup berbangsa dan bernegara ini harus menjadi haluan pembangunan bangsa Indonesia melalui proses sosialisasi, pendidikan dan pembelajaran, pembudayaan, dan kerja sama seluruh komponen bangsa dan Negara secara koheren. Karakter bangsa Indonesia yang terbentuk dari karakterkarakter individu adalah karakter yang berlandaskan falsafah Pancasila yang dijiwai dari ke-lima sila Pancasila secara utuh dijabarkan sebagai karakter pribadi bangsa Indonesia sebagai karakter berKetuhanan Yang Maha Esa, karakter kemanusiaan, karakter kebangsaan, karakter kerakyatan, dan karakter berkeadilan sosial. Fokus penelitian yang dilaporkan di sini difokuskan pada evaluasi muatan karakter kebangsaan sebagai karakter pribadi bangsa Indonesia yang merupakan pencerminan sila ketiga Pancasila.

Karakter kebangsaan memiliki beberapa indikator pencerminan karakter bangsa Indonesia dari sila ketiga Pancasila "Persatuan Indonesia" yaitu: menempatkan persatuan, kesatuan, kepentingan dan keselamatan bangsa di atas kepentingan pribadi atau golongan, rela berkorban demi kepentingan bangsa dan Negara, bangga sebagai bangsa Indoensia yang bertanah air Indonesia serta menjunjung tinggi bahasa Indonesia, dan memajukan pergaulan demi persatuan dan kesatuan bangsa yang ber-Bbinneka Tunggal Ika.

Karakter kebangsaan yang terbentuk dengan baik di sekolah secara langsung dan tidak langsung merupakan upaya pembentukan sikap dan kesadaran nasionalisme suatu bangsa dalam menghadapi masa depan yang penuh dengan tantangan. Tantangan masa depan yang diwarnai dengan pesatnya kemajuan teknologi komunikasi dan informasi, interaksi antarbangsa, antarkebudayaan, dan antar peradaban semakin mencair, terbuka di dunia virtual yang nyaris tidak mengenal batas ruang dan waktu (Sumarno, 2011, p.74), dapat berdampak pada terkikisnya identitas diri dan pudarnya karakter bangsa. Ancaman pudarnya karakter bangsa ini menjadikan penyusunan suatu model evaluasi kurikulum amat strategis dalam kaitannya dengan pemanfaatan informasi yang diperoleh dari hasil evaluasi terhadap kurikulum tersebut.

Informasi yang diperoleh dari data hasil evaluasi digunakan untuk tiga macam keputusan, yaitu menentukan perlu tidaknya perubahan materi dan metode pembelajaran, perencanaan pembelajaran, menginformasikan kemajuan peserta didik, dan menilai efektifitas suatu program atau seorang pengajar (Davis, 1980, p.25). Dalam hal ini, evaluasi kurikulum dipandang sebagai suatu proses pengumpulan dan penggunaan informasi yang akan digunakan untuk membuat keputusan terhadap suatu program pendidikan, dan memberikan rekomendasi yang diperlukan dalam pengambilan keputusan.

Proses pengumpulan dan penggunaan informasi untuk mengambil keputusan dalam evaluasi kurikulum dilakukan untuk menjawab pertanyaan tentang seberapa baik pelaksanaan suatu kurikulum termasuk upaya yang dilakukan dalam mencapai tujuan (Beane, Toepfer \& Alessi, 1986, p.265). Karena itu, evaluasi harus dilakukan secara berkesinambungan pada seluruh aspek kurikulum dengan memperhatikan pertanyaan tentang tujuan, elemen-elemen perencanaan awal apakah sesuai dengan kebutuhan, minat, dan karakteristik peserta didik, kuali- 
tas interaksi antara peserta didik dan guru, performa guru dan peserta didik selama PBM, dan tercapainya tujuan yang telah ditetapkan (Davis, 1980, p.23). Dengan demikian, peranan guru/dosen dalam melakukan evaluasi kurikulum menjadi sangat strategis sebagai pihak yang dapat mengobservasi, mendeskripsikan, dan menganalisis interaksi yang terjadi di dalam kelas.

Mengingat pentingnya peranan guru/ dosen dalam melakukan evaluasi kurikulum, tiap lembaga pendidikan termasuk pendidikan bahasa Inggris perlu senantiasa melakukan evaluasi kurikulum secara internal demi memastikan penuangan muatan karakter bangsa dalam kurikulum pembelajaran yang diberikan. Untuk itu, evaluasi kurikulum yang mampu menangkap adanya penuangan karakter bangsa dalam perencanaan dan implementasi kurikulum diperlukan sebagai alat kontrol dan bahan penyedia masukan bagi pimpinan lembaga pendidikan dan juga bagi staf pengajar bahasa asing itu sendiri seperti yang akan dilaporkan dalam penelitian ini.

Model evaluasi reflektif kurikulum pendidikan bahasa Inggris dalam pengembangan karakter bangsa yang dikembangkan dalam penelitian ini memuat elemen-elemen evaluasi kurikulum, yaitu: muatan karakter bangsa dalam konteks kurikulum, pengetahuan dosen tentang pendidikan karakter bangsa, muatan karakter bangsa dalam bahan ajar, muatan karakter bangsa dalam proses pembelajaran, dan evaluasi produk pembelajaran afeksi. Hubungan konseptual model evaluasi disajikan pada Gambar 1.

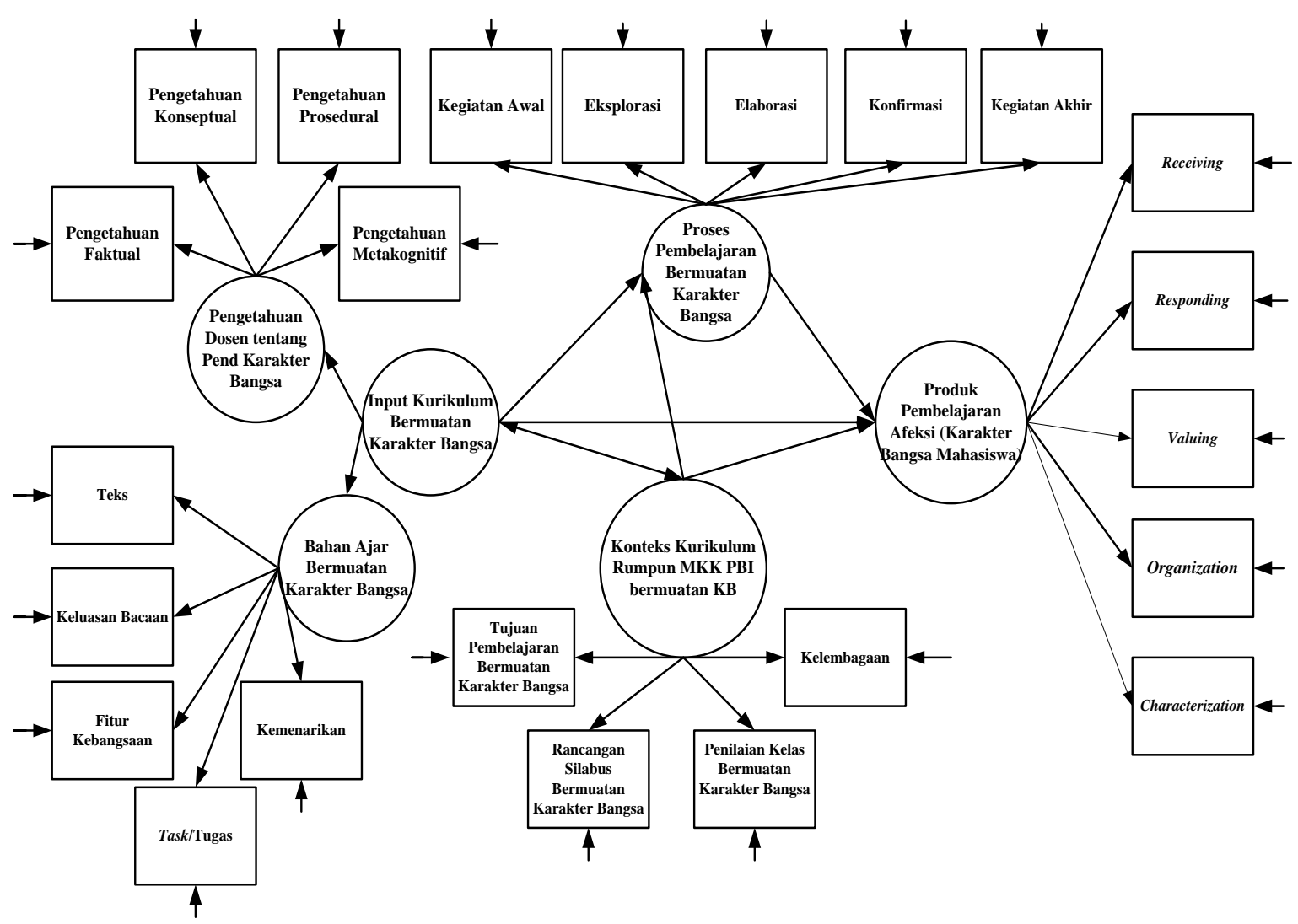

Gambar 1. Kerangka Konseptual Model Evaluasi Reflektif Kurikulum MKKPBIKB

Prosedur kegiatan evaluasi yang dikembangkan merupakan hasil modifikasi model evaluasi CIPP dari Stufflebeam dan kawan-kawan yang dipadu dengan komponen-komponen evaluasi dalam Logic Model yang disajikan pada Gambar 2. Terkait de- ngan hal tersebut, penelitian ini bertujuan untuk mengembangkan model evaluasi reflektif kurikulum rumpun mata kuliah keahlian pendidikan bahasa Inggris untuk memotret penuangan nilai-nilai karakter bangsa di dalam kelas. 


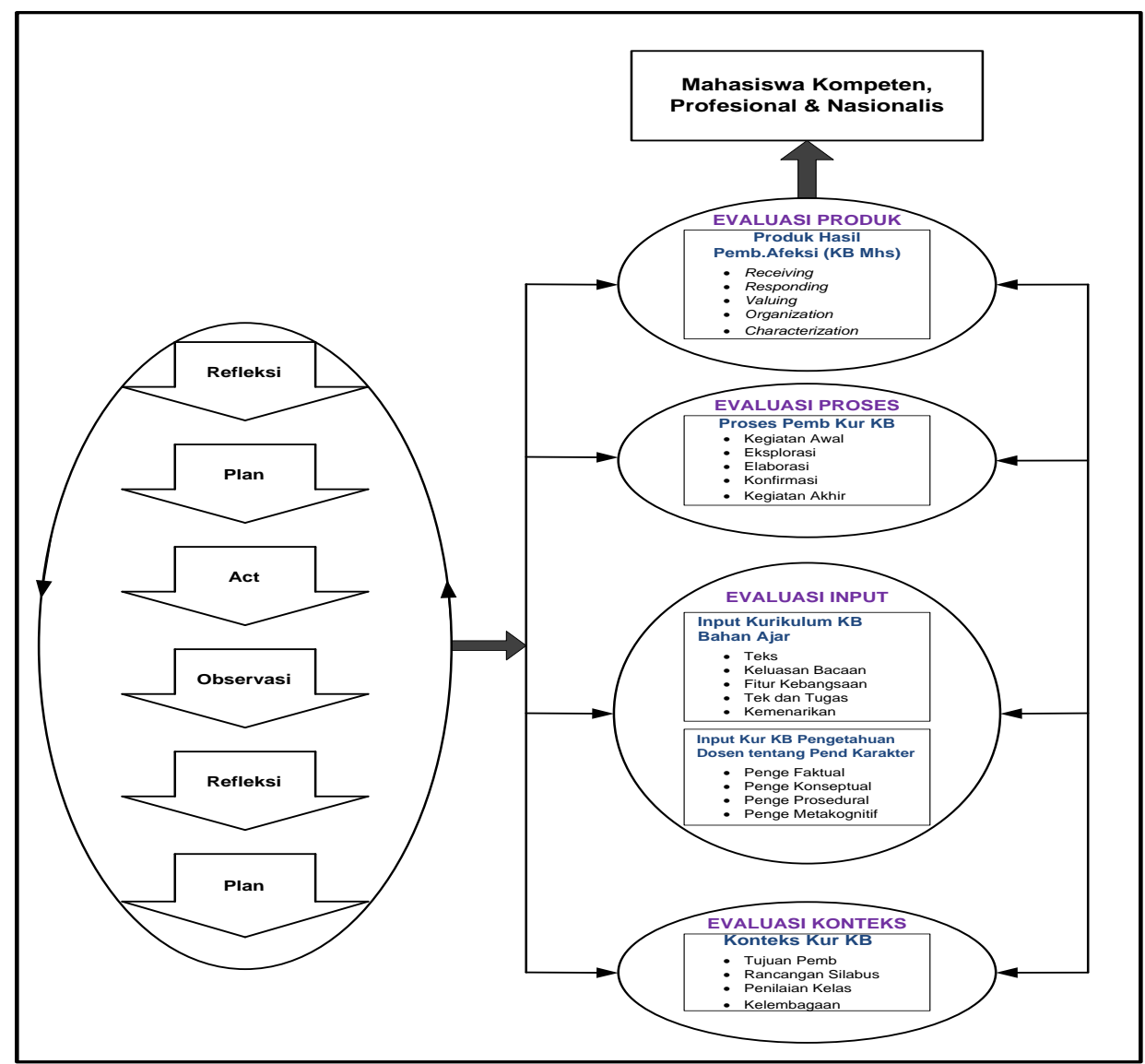

Gambar 2. Prosedur Kegiatan Evaluasi Reflektif Kurikulum Rumpun MKK PBI dalam Pengembangan Karakter Bangsa

\section{Metode Penelitian}

Jenis Penelitian

Penelitian ini menggunakan pendekatan kualitatif dan kuantitatif (campuran). Pendekatan ini digunakan untuk membantu menjelaskan hal-hal yang tidak dapat dijelaskan dengan pendekatan kuantitatif semata, seperti menjelaskan apabila terdapat bias, underestimated atau overestimated penilaian oleh responden. Pengembangan model ini mengadaptasi tahapan pengembangan model spiral dari Cennamo \& Kalk (2005) dengan tahapan seperti berikut: (1) penelitian, (2) pendefinisian, (3) perancangan, (4) peragaan, dan (5) pengembangan.

Model dikembangkan mengadaptasi model spiral dimana tiap fase diuraikan sebagai berikut: fase pertama terdiri dari kegiatan penelitian kajian pustaka dan hasilhasil penelitian, penggalian informasi mengenai penerapan pendidikan karakter dalam kurikulum pembelajaran, pengumpulan data tentang upaya Prodi PBI dalam penuangan muatan karakter bangsa melalui kegiatan prasurvei, tahap kedua dilakukan penentuan lingkup kegiatan, produk pengembangan yang akan dihasilkan, subjek uji, populasi, instrumen dan teknik analisis data yang akan digunakan dan jadwal kegiatan. tahap ketiga dilakukan perencanaan rancangan model, pola dasar, alur kerja, dan instrumen evaluasi reflektif kurikulum MKK PBI dalam pengembangan karakter bangsa, tahap keempat dilakukan kegiatan pengujian produk yang merupakan kegiatan pengujian kelompok terbatas yang dilanjutkan dengan kegiatan revisi dan analisis sampai akhirnya dihasilkan model tentatif evaluasi reflektif kurikulum MKK PBI dalam pengembangan karakter bangsa, dan tahap kelima adalah tahap lanjutan dari tahap peragaan (demonstrate) yaitu berupa kegiatan pengujian lapangan utama dan kegiatan revisi/modifikasi model. 
Waktu dan Tempat Penelitian

Tahapan penelitian terdiri atas tahap penelitian dan tahap pengembangan yang dilaksanakan di empat Prodi Pendidikan bahasa Inggris yang ada di DIY, yaitu Prodi Pendidikan Bahasa Inggris Universitas Sanata Dharma (USD), Universitas Sarjanawiyata Tamansiswa (UST), Universitas Negeri Yogyakarta (UNY), dan Universitas Ahmad Dahlan (UAD) selama kurang lebih 1 tahun.

\section{Subjek Penelitian}

Penelitian ini merupakan penelitian yang pemilihan sampelnya menggunakan metode purposive sampling dengan subjek penelitian melibatkan responden sebanyak 5 orang dosen dan 70 orang mahasiswa pada kegiatan uji coba pertama (kelompok terbatas) dan sebanyak responden 20 orang dosen dan 291 orang mahasiswa dari 4 Prodi Pendidikan Bahasa Inggris yang ada di DIY, yaitu USD, UST, UNY, dan UAD.

\section{Prosedur}

Prosedur yang dilakukan dalam penelitian pengembangan ini terdiri dari tahap penelitian dan tahap pengembangan model, sehingga dengan mengadaptasi prosedur pengembangan dari model spiral Cennamo \& Kalk (2005) prosedur penelitian ini terdiri dari 5 tahap, yaitu: tahap penelitian, pendefinisian, perancangan, peragaan, dan pengembangan.

Pada tahap penelitian dilakukan kegiatan penelitian kajian pustaka dan hasilhasil penelitian terkait berbagai teori tentang kurikulum, karakter bangsa, model evaluasi, dan model evaluasi kurikulum, sehingga dapat ditentukan komponen-komponen model evaluasi yang dikembangkan. Selanjutnya, pada tahap ini juga dilakukan kegiatan penggalian informasi mengenai penerapan pendidikan karakter dan upaya menuangkan muatan karakter bangsa dalam proses pembelajaran dengan melakukan observasi keempat program studi pendidikan bahasa Inggris di DIY, serta wawancara dengan Ketua Program Studi, Kepala dan Sekretaris Penjaminan Mutu, dan beberapa dosen di program studi pendidikan bahasa Inggris tersebut.
Untuk melengkapi data tentang masing-masing program studi, peneliti mengumpulkan dan mencermati dokumen program studi berupa buku kurikulum, pedoman model pembelajaran, buku karya pemikiran akademik sivitas akademik, pedoman evaluasi pembelajaran, uraian tentang kurikulum, sejarah, tujuan pendidikan, visi dan misi, course outline, rubrik penilaian, bahan kuliah, materi-materi khusus, pedoman akademik 2012/2013 Fakultas Keguruan dan Ilmu Pendidikan, dan juga refleksi konsep pendidikan (Ki Hadjar Dewantara, Kemuhammadiyahand an Pedagogi Ignasian).

Pada tahap pengembangan model dilakukan kegiatan penelitian yang mengadaptasi model pengembangan Cennamo \& Kalk (2005) terdiri dari 5 tahap kegiatan, yaitu pendefinisian, perancangan, peragaan, pengembangan, dan penyajian. Pada tahap pendefinisian dilakukan kegiatan telaah kebutuhan, konstruk, dan kriteria model evaluasi, dilanjutkan dengan perancangan model, alur kerja dan instrumen evaluasi. Pada tahap selanjutnya dilakukan kegiatan peragaan yaitu berupa kegiatan pengujian lapangan pada kelompok terbatas dan dilanjutkan dengan revisi dan analisis, diteruskan dengan kegiatan pengembangan model pada kelompok yang lebih besar, revisi dan analisis, hingga menghasilkan model yang telah direvisi. Kegiatan selanjutnya adalah kegiatan lanjutan berupa penyajian/sosialisasi dna pengumpulan saran, masukan, dan pengembangan lanjutan yang akan dilakukan dalam penelitian lanjutan. Prosedur pengembangan model disajikan pada Gambar 3.

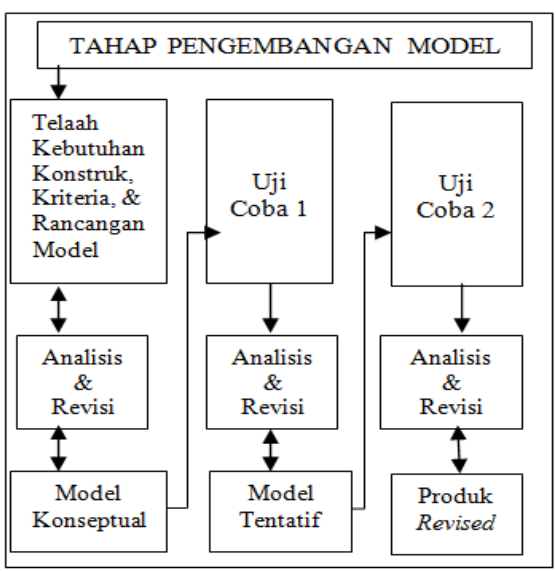

Gambar 3.Tahapan Pengembangan Model 
Data, Intrumen, dan Teknik Pengumpulan Data

Jenis data yang akan diperoleh terdiri dari data kualitatif yang diperoleh dari hasil telaah pustaka, hasil wawancara, observasi kelas, dan studi dokumen terhadap Ketua Program Studi, dan dosen dari Prodi PBI USD, UST, UNY, dan UAD, dan data kuantitatif diperoleh dari hasil olah CVR (content validity ration) dari penilaian rekan sejawat, dari hasil penyebaran angket, data hasil uji model dari pengolahan data menggunakan analisis faktor konfirmatori (CFA) dengan program SmartPLS dan juga uji kecocokan model menggunakan program GeSCA.

Instrumen yang digunakan berdasarkan jenis data yang terdiri dari wawancara, diskusi terbuka dalam kegiatan FGD, teknik Delphy untuk kegiatan penilaian pakar, lembar pengamatan untuk memperoleh data observasi pelaksanaan pembelajaran di dalam kelas, dan angket terstruktur untuk informasi penilaian dosen dan mahasiswa tentang penuangan muatan karakter bangsa dalam kurikulum pembelajaran pendidikan bahasa Inggris.

\section{Teknik Analisis Data}

Teknik analisis data kualitatif menggunakan teknik analisis deskriptif dalam menganalisis kajian pustaka dalam membangun teori terkait konstruk dan kriteria dalam model evaluasi yang dikembangkan, mendeskripsikan hasil penilaian pakar, dan deskripsi tentang hasil uji coba pada kelompok terbatas maupun uji coba lapangan yang lebih luas dengan menggunakan crosscase analysis.

Teknik analisis data kuantitatif menggunakan CVR (content validity ration) dalam melakukan uji validitas isi, analisis faktor konfirmatori (CFA) dalam menganalisis data hasil uji coba kelompok terbatas dan kelompok yang lebih luas dengan program SmartPLS, analisis reliabilitas komposit dan Alpha dalam melihat konsistensi internal butir instrumen, dan analisis uji kecocokan model menggunakan program GeSCA untuk melihat apakah model yang dikem- bangkan telah sesuai atau cocok antara teori dan penerapannya di lapangan.

\section{Hasil Penelitian dan Pembahasan}

Hasil penelitian terdiri dari hasil pengembangan dan hasil uji coba produk. Data yang dihasilkan pada hasil pengembangan terbagi atas hasil penelitian dan hasil pengembangan sedangkan hasil uji coba produk terbagi atas hasil validitas isi, seleksi butir dan reliabilitas instrumen, uji kecocokan model, dan kriteria penyekoran (kategorisasi) berdasarkan model yang dikembangkan.

\section{Hasil Pengembangan}

\section{Hasil Penelitian}

Hasil penelitian menunjukkan beberapa permasalahan dalam penerapan pendidikan karakter bangsa dalam kurikulum pembelajaran pendidikan bahasa Inggris yang ada di Provinsi DIY adalah (1) konteks kurikulum MKK dituangkan masih secara implisit sehingga perlu diperiksa lebih lanjut muatan karakter bangsa dalam kurikulum MKK yang diselenggarakan, (2) pengetahuan dosen tentang pendidikan karakter di keempat Prodi dipandang sudah tinggi, tetapi pelatihan tentang penuangan nilainilai karakter tersebut belum terprogram secara rutin, (3) belum ada mekanisme yang dapat digunakan untuk memeriksa muatan karakter bangsa dalam bahan ajar yang diberikan, (4) belum ada wadah yang mengakomodir informasi tentang muatan karakter bangsa dalam proses pembelajaran baik itu dari dosen maupun mahasiswa, dan (5) penelusuran tentang produk pembelajaran afeksi (karakter bangsa mahasiswa) masih belum banyak disentuh demi memastikan internalisasi nilai-nilai kebangsaan dalam diri mahasiswa.

\section{Hasil Pengembangan}

Hasil pengembangan menunjukkan bahwa pada tahap pendefinisian (defining) dihasilkan rumusan komponen model evaluasi untuk mengidentifikasi muatan karakter bangsa dalam kurikulum MKK PBI yang terdiri atas empat aspek yaitu: (1) muatan karakter bangsa dalam konteks kurikulum 
MKK PBI, (2) muatan karakter bangsa dalam input kurikulum MKK PBI, (3) muatan karakter bangsa dalam PBM, dan (4) produk pembelajaran afeksi (karakter bangsa mahasiswa).

Tahap perancangan (designing) menghasilkan kisi-kisi instrumen evaluasi muatan karakter bangsa dalam kurikulum MKK PBI dengan total jumlah 141 butir. Selanjutnya dilakukan validasi, analisis, dan revisi sebanyak 4 kali dan uji coba sebanyak 2 kali untuk mengetahui apakah indikator yang disusun dalam kisi-kisi sudah terwakili dalam instrumen yang dikembangkan.

Pada tahap validasi teman sejawat jumlah butir yang tidak dapat dipertahankan sebanyak 12 butir sehingga total jumlah butir menjadi 129 butir yang tersebar dalam 5 instrumen. Pada tahap validasi isi yang melibatkan 10 orang panelis, sebanyak 6 butir yang tidak dapat dipertahankan sehingga total butir menjadi 123 butir yang tersebar pada 5 instrumen. Pada tahap validasi pakar dihasilkan validasi dan revisi kejelasan tujuan evaluasi dan komponen evaluasi muatan karakter bangsa dalam kurikulum MKK PBI, kriteria penyekoran, dan instrumen evaluasi. Pada tahap validasi praktisi dihasilkan revisi kejelasan model evaluasi, instrumen evaluasi, dan panduan evaluasi berdasarkan saran dan masukan para praktisi.

Tahap peragaan (demonstrating) menghasilkan revisi hasil uji coba instrumen tahap pertama berdasarkan informasi empirik butir-butir yang termuat dalam instrumen evaluasi yang dikembangkan, menggunakan analisis faktor konfirmatori. Dukungan tiap item terhadap faktor-faktor dan reliabilitas komposit tiap instrumen disajikan pada Tabel 1.

Tahap pengembangan (developing) menghasilkan revisi analisis uji coba tahap kedua berdasarkan informasi empirik tentang butir-butir yang termuat dalam instrumen evaluasi menggunakan analisis faktor konfirmatori dengan menunjukkan dukungan tiap item terhadap faktor-faktor dan reliabilitas komposit tiap instrumen disajikan pada Tabel 2.
Tabel 1. Sebaran Butir Instrumen Uji Coba Tahap Pertama

\begin{tabular}{lccc}
\hline \multicolumn{1}{c}{$\begin{array}{c}\text { Instrumen } \\
\text { Evaluasi }\end{array}$} & $\begin{array}{c}\text { Butir } \\
\text { Terpakai }\end{array}$ & $\begin{array}{c}\text { Rel } \\
\text { komp }\end{array}$ & $\begin{array}{c}\text { Jumlah } \\
\text { Resp }\end{array}$ \\
\hline $\begin{array}{l}\text { Muatan KB } \\
\text { dlm Konteks }\end{array}$ & 25 & 0,94 & 75 \\
$\begin{array}{l}\text { KurMKK PBI } \\
\text { Pengetahuan }\end{array}$ & 17 & 0,92 & 75 \\
$\begin{array}{l}\text { Dosen ttg Pend } \\
\text { Karakter } \\
\text { Muatan KB } \\
\text { dlm Bahan Ajar }\end{array}$ & 18 & 0,96 & 75 \\
$\begin{array}{l}\text { Muatan KB } \\
\text { dlm PBM }\end{array}$ & 34 & 0,92 & 75 \\
$\begin{array}{l}\text { Produk Pemb } \\
\text { Afeksi }\end{array}$ & 29 & 0,88 & 75 \\
\hline \multicolumn{1}{c}{ Jumlah } & 123 & & 75 \\
\hline
\end{tabular}

Tabel 2. Sebaran Butir Instrumen Uji Coba Tahap Kedua

\begin{tabular}{lccc}
\hline \multicolumn{1}{|l}{ Instrumen Evaluasi } & $\begin{array}{c}\text { Butir } \\
\text { Terpakai }\end{array}$ & $\begin{array}{c}\text { Rel } \\
\text { komp }\end{array}$ & $\begin{array}{c}\text { Jumlah } \\
\text { Resp }\end{array}$ \\
\hline $\begin{array}{l}\text { Muatan KB dlm } \\
\text { Konteks KurMKK }\end{array}$ & 20 & 0,95 & 311 \\
$\begin{array}{l}\text { PBI } \\
\begin{array}{l}\text { Pengetahuan Dosen } \\
\text { ttg Pend Karakter }\end{array}\end{array}$ & 17 & 0,92 & 311 \\
$\begin{array}{l}\text { Muatan KB dlm } \\
\text { Bahan Ajar } \\
\text { Muatan KB dlm }\end{array}$ & 17 & 0,95 & 311 \\
$\begin{array}{l}\text { PBM } \\
\text { Produk Pemb } \\
\text { Afeksi }\end{array}$ & 27 & 0,94 & 311 \\
\hline \multicolumn{1}{c}{ Jumlah } & 23 & 0,88 & 311 \\
\hline
\end{tabular}

Hasil Uji Coba Produk

Validitas Isi

Instrumen yang telah direvisi berdasarkan masukan teman sejawat selanjutnya dinilai kembali oleh 10 orang panelis yang memiliki keahlian dalam bidang evaluasi, pengukuran, pendidikan, statistik, dan psikologi, untuk melihat relevansi antara indikator dan butir. Masukan panelis terhadap kelima instrumen dianalisis menggunakan content validity ratio (CVR) dari Lawshe (1975) dengan rumus berikut:

$$
\operatorname{CVR}=\frac{n_{e}-N_{2}}{N_{2}}
$$

Keterangan:

$\mathrm{n}_{\mathrm{e}} \quad$ : Jumlah panelis yang berpendapat butir relevan $\mathrm{N}_{2}$ : Jumlah total panelis

Hasil analisis validitas isi mengggunakan analisis CVR (content validity ratio) oleh 
10 orang panelis menunjukkan bahwa terdapat total 6 butir tidak berkualitas karena tidak memenuhi nilai minimum CVR 0,62 sedangkan hasil analisis validitas instrumen dengan menggunakan CVI (content validity index) diperoleh indeks validitas isi kelima instrumen valid karena memenuhi nilai CVI $>$ 0,51 (Lawshe, 1975, p.572), berikut ini:

Tabel 3. Hasil Analisis CVR Instrumen Evaluasi Reflektif Kurikulum MKKPBIKB

\begin{tabular}{lcc}
\hline \multicolumn{1}{c}{ Instrumen Evaluasi } & $\begin{array}{c}\text { Butir } \\
\text { Berkualitas }\end{array}$ & $\begin{array}{c}\text { Butir Tdk } \\
\text { Berkualitas }\end{array}$ \\
\hline $\begin{array}{l}\text { Muatan KB dlm } \\
\text { Konteks Kur MKK }\end{array}$ & 25 & 2 \\
$\begin{array}{l}\text { PBI } \\
\begin{array}{l}\text { Pengetahuan Dosen } \\
\text { ttg Pend Karakter }\end{array}\end{array}$ & 17 & 1 \\
$\begin{array}{l}\text { Muatan KB dlm } \\
\text { Bahan Ajar } \\
\text { Muatan KB dalam }\end{array}$ & 18 & - \\
$\begin{array}{l}\text { PBM } \\
\text { Produk Pemb Afeksi }\end{array}$ & 34 & 1 \\
\hline \multicolumn{1}{c}{ Jumlah } & 29 & 2 \\
\hline
\end{tabular}

Tabel 4. CVI Instrumen Evaluasi Reflektif Kurikulum MKKPBIKB

\begin{tabular}{ll}
\hline \multicolumn{2}{c}{ CVI Instrumen Evaluasi } \\
\hline $\begin{array}{l}\text { Muatan KB dlm konteks Kurikulum } \\
\text { MKK PB }\end{array}$ & 0,86 \\
$\begin{array}{l}\text { Pengetahuan Dosen ttg Pendidikan } \\
\text { Karakter }\end{array}$ & 0,94 \\
Muatan KB dlm Bahan Ajar & 0,94 \\
Muatan KB dalam PBM & 0,91 \\
Produk Pembelajaran Afeksi & 0,94 \\
\hline
\end{tabular}

\section{Seleksi Butir dan Reliabilitas Instrumen}

Analisis data hasil uji coba instrumen evaluasi dilakukan dalam dua tahap, yakni uji coba pada kelompok terbatas dan uji coba pada kelompok yang lebih besar dengan melakukan analisis faktor konfirmatori menggunakan program SmartPLS Versi 2.03 M3 oleh Ringle, Wende \& Will (2005). Hal ini bertujuan melihat dukungan tiap item terhadap faktor-faktor yang terdapat dalam tiap indikator atau kekuatan hubungan pada masing-masing indikator terhadap variabel laten yang terdapat dalam instrumen evaluasi yang dikembangkan. Berikut hasil seleksi butir kelima instrumen:
Tabel 5. Seleksi butir pada Uji Coba Instrumen Tahap Pertama

\begin{tabular}{lccc}
\hline \multicolumn{1}{|l}{ Instrumen Evaluasi } & $\begin{array}{c}\text { Butir } \\
\text { Terpakai }\end{array}$ & $\begin{array}{c}\text { Rel } \\
\text { komp }\end{array}$ & $\begin{array}{c}\text { Jumlah } \\
\text { Resp }\end{array}$ \\
\hline $\begin{array}{l}\text { Muatan KB dlm } \\
\text { Konteks Kur MKK }\end{array}$ & 20 & 0,95 & 75 \\
$\begin{array}{l}\text { PBI } \\
\begin{array}{l}\text { Pengetahuan Dosen } \\
\text { ttg Pend Karakter }\end{array}\end{array}$ & 17 & 0,92 & 75 \\
$\begin{array}{l}\text { Muatan KB dlm } \\
\text { Bahan Ajar }\end{array}$ & 17 & 0,95 & 75 \\
$\begin{array}{l}\text { Muatan KB dlm } \\
\text { PBM }\end{array}$ & 27 & 0,94 & 75 \\
Produk Pemb Afeksi & 23 & 0,88 & 75 \\
\hline Jumlah & 106 & & 75 \\
\hline
\end{tabular}

Tabel 6. Seleksi butir pada Uji Coba Instrumen Tahap Kedua

\begin{tabular}{lccc}
\hline \multicolumn{1}{|c}{ Instrumen Evaluasi } & $\begin{array}{c}\text { Butir } \\
\text { Terpakai }\end{array}$ & $\begin{array}{c}\text { Rel } \\
\text { komp }\end{array}$ & $\begin{array}{c}\text { Jumlah } \\
\text { Resp }\end{array}$ \\
\hline $\begin{array}{l}\text { Muatan KB dlm } \\
\text { Konteks Kur MKK }\end{array}$ & 20 & 0,95 & 311 \\
$\begin{array}{l}\text { PBI } \\
\begin{array}{l}\text { Pengetahuan Dosen } \\
\text { ttg Pend Karakter }\end{array}\end{array}$ & 17 & 0,92 & 311 \\
$\begin{array}{l}\text { Muatan KB dlm } \\
\text { Bahan Ajar }\end{array}$ & 17 & 0,95 & 311 \\
$\begin{array}{l}\text { Muatan KB dlm } \\
\text { PBM }\end{array}$ & 25 & 0,95 & 311 \\
Produk Pemb Afeksi & 21 & 0,88 & 311 \\
\hline Jumlah & 100 & & 311 \\
\hline
\end{tabular}

Untuk menetapkan butir-butir yang akan digunakan dilakukan analisis korelasi butir yang memiliki koefisien korelasi butir terhadap total sebesar $\geq 0,30$ dengan muatan faktor $\geq 0,5$ dan reliabilitas komposit $>$ 0,70 seperti berikut:

Tabel 7. Penetapan Butir Setelah Seleksi Butir pada Uji Coba Instrumen Tahap Kedua

\begin{tabular}{lccc}
\hline \multicolumn{1}{c}{ Instrumen Evaluasi } & $\begin{array}{c}\text { Butir } \\
\text { Terpakai }\end{array}$ & $\begin{array}{c}\text { Rel } \\
\text { komp }\end{array}$ & $\begin{array}{c}\text { Jumlah } \\
\text { Resp }\end{array}$ \\
\hline $\begin{array}{l}\text { Muatan KB dlm } \\
\text { Konteks Kur MKK }\end{array}$ & 19 & 0,95 & 311 \\
$\begin{array}{l}\text { PBI } \\
\text { Pengetahuan Dosen }\end{array}$ & 17 & 0,92 & 311 \\
ttg Pend Karakter & & & \\
$\begin{array}{l}\text { Muatan KB dlm Bahan } \\
\text { Ajar }\end{array}$ & 17 & 0,95 & 311 \\
$\begin{array}{l}\text { Muatan KB dlm PBM } \\
\text { Produk Pemb Afeksi }\end{array}$ & 25 & 0,95 & 311 \\
\hline Jumlah & 14 & 0,85 & 311 \\
\hline
\end{tabular}


Tabel 8. Reliabilitas Kelima Instrumen Evaluasi Reflektif Kurikulum MKKPBIKB

\begin{tabular}{lc}
\hline \multicolumn{1}{c}{$\begin{array}{c}\text { Instrumen } \\
\text { Evaluasi }\end{array}$} & $\begin{array}{c}\text { Reliabilitas } \\
\text { Komposit }\end{array}$ \\
\hline $\begin{array}{l}\text { Muatan KB dlm konteks } \\
\text { Kurikulum MKK PB } \\
\text { Pengetahuan Dosen ttg Pend }\end{array}$ & 0,93 \\
Karakter & 0,91 \\
Muatan KB dlm Bahan Ajar & 0,95 \\
Muatan KB dalam PBM & 0,95 \\
\hline Produk Pemb Afeksi & 0,86 \\
\hline
\end{tabular}

\section{Uji Kecocokan Model}

Sebelum dilakukan uji kecocokan model menggunakan model persamaan struktural, terlebih dahulu dilakukan uji kelayakan variabel dengan menggunakan Program PASW 18. Jika nilai Kaiser-Meyer-Olkin $(\mathrm{KMO}) \geq$ 0,50 dan nilai signifikansi pada Bartlett's Test of Sphericity $\leq$ 0,05 maka variabel layak diuji lebih lanjut. Hasil uji kelayakan menunjukkan bahwa variable layak diuji lebih lanjut karena memiliki nilai $\mathrm{KMO}=0,917$ dan nilai signifikansi Bartlett's Test of Sphericity $\leq 0,05$ seperti ditunjukkan pada Tabel 9 .

Tabel 9. Nilai KMO dan Bartlett's Test

\begin{tabular}{lc}
\hline Kaiser-Meyer-Olkin Measure of & 0,917 \\
Sampling Adequacy & \\
Bartlett's Test of Sphericity & \\
Approx. Chi-Square & 3372,478 \\
Df & 253 \\
Sig. & 0,000 \\
\hline
\end{tabular}

Selanjutnya, untuk menganalisis model persamaan struktural digunakan software program SmartPLS Versi 2.0 yang merupakan analisis model persamaan struktural berbasis komponen dari Ringle, Wende \& Will (2005), sedangkan untuk uji kecocokan model digunakan software program Generalized Structured Component Analysis (GeSCA) yang dikembangkan oleh Heungsun Hwang (2011).

Untuk menguji fit model, digunakan pasangan hipotesis sebagai berikut:
$\mathrm{H}_{0}$ : Model sesuai dengan/didukung data

$\mathrm{H}_{1}$ : Model tidak sesuai dengan/didukung data

Kriteria ujinya adalah:

Terima $\mathrm{H}_{0}$ bila nilai GFI mendekati 1 atau $\geq 0,98$ dan SRMR (standardized root mean square residual) mendekati 0 atau $\leq 0,08$ merupakan indikasi kelayakan model yang dapat diterima

Terima $\mathrm{H}_{1}$ bila nilai GFI mendekati 0 dan SRMR (standardized root mean square residual) mendekati 1.

Hasil uji kelayakan model evaluasi reflektif kurikulum rumpun MKK pendidikan bahasa Inggris dalam pengembangan karakter bangsa disajikan pada Tabel 10.

Tabel 10. Uji Kecocokan Model Evaluasi Reflektif Kurikulum MKKPBIKB

\begin{tabular}{cc}
\hline \multicolumn{3}{c}{ Model Fit } \\
\hline FIT & 0,64 \\
AFIT & 0,64 \\
GFI & 0,99 \\
SRMR & 0,06 \\
NPAR & 97 \\
\hline
\end{tabular}

Pada tabel di atas tampak bahwa nilai FIT sebesar 0,64 dan AFIT sebesar 0,64 menunjukkan bahwa model yang dispesifikasi mampu menjelaskan $64 \%$ varians pada data. Nilai GFI (unweight least squares/Goodness of Fit) sebesar 0,99 dan SRMR (standardized root mean square residual) sebesar 0,06 menunjukkan model fit yang baik karena nilai GFI mendekati 1 atau $\geq 0,98$ dan SRMR mendekati 1 atau $\leq 0,08$. Dengan demikian dapat disimpulkan bahwa model teoritik yang dikembangkan didukung oleh data empirik.

Hasil analisis menunjukkan bahwa konstruk model EvalRefKurMKKPBIKB mengalami perubahan pada jumlah subvaribel laten dari empat menjadi lima yaitu dengan 2 variabel input yaitu pengetahuan dosen dan bahan ajar seperti pada Gambar 4. 


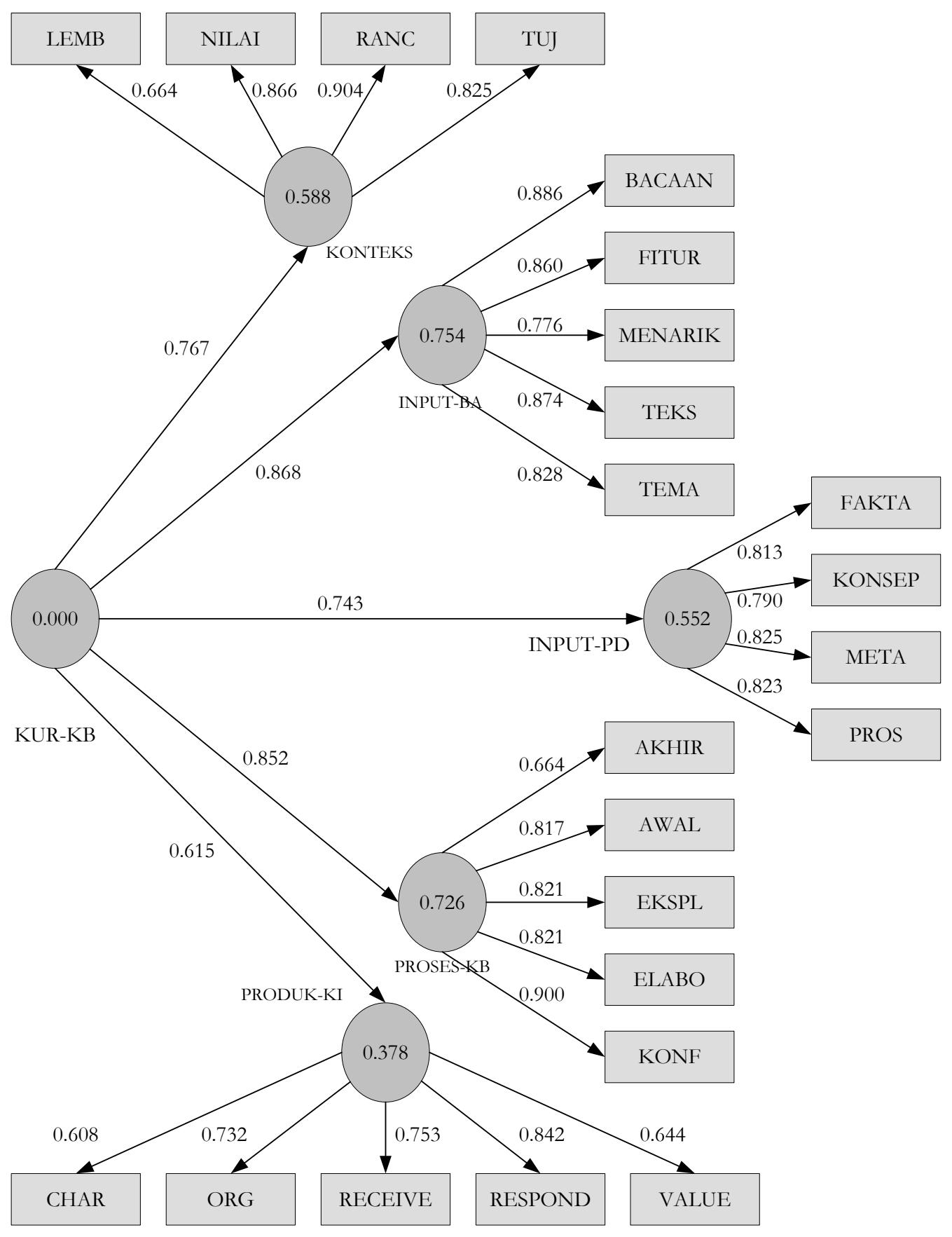

Gambar 1. Model Empirik Instrumen Evaluasi Reflektif Kurikulum MKKPBIKB

Konstruk kurikulum bermuatan karakter bangsa dibentuk oleh sub-konstruk konteks kurikulum MKK PBI bermuatan karakter bangsa, sub-konstruk input menghasilkan 2 dimensi yaitu bahan ajar bermuatan karakter bangsa dan pengetahuan dosen tentang pendidikan karakter bangsa, sub-konstruk muatan karakter bangsa dalam PBM dan sub-konstruk produk hasil pembelajaran afeksi (karakter bangsa mahasiswa).
Secara teoretik konstruk input hanya terdiri dari 1 dimensi, ternyata setelah diterapkan di lapangan menghasilkan 2 dimensi yaitu dimensi bahan ajar bermuatan karakter bangsa dan dimensi pengetahuan dosen tentang pendidikan karakter, sehingga konstruk kurikulum MKK PBI bermuatan karakter bangsa menjadi model C-I-I-P-P (ContextInput-Input-Process-Product). 
Kriteria Penyekoran (Kategorisasi) Model Evaluasi Reflektif Kurikulum Rumpun MKK PBI dalam Pengembangan Karakter Bangsa

Kriteria penyekoran atau kategorisasi menggunakan kriteria pacuan norma (norm reference) dengan menguji signifikansi perbedaan antara mean skor/sampel dan mean skor teoretik/populasi dan mengkategorikan ke jenjang Rendah, Sedang, dan Tinggi (Azwar, 2012, pp.154-8). Penentuan skor dilakukan dengan menetapkan kategori Tengah/Sedang, dengan menghitung batasbawah dan batas-atas internal skor-skor yang berbeda secara signifikan dari harga suatu mean populasi, menurut tingkat kepercayaan yang diinginkan dengan rumusan:

\begin{tabular}{|c|c|}
\hline \multicolumn{2}{|c|}{ 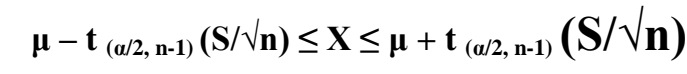 } \\
\hline$\mu$ & : Mean teoritis pada skala \\
\hline $\mathrm{t}_{(\alpha / 2, \mathrm{n}-1)}$ & $\begin{array}{l}\text { : Harga t pada } \alpha / 2 \text { dan derajat } \\
\text { kebebasan } n-1\end{array}$ \\
\hline S & : Deviasi standar skor \\
\hline $\mathrm{N}$ & : Banyaknya subyek \\
\hline
\end{tabular}

Hasil output one-sample statistics dari SPSS menunjukkkan harga Std. Error Means tiap indikator dalam konstruk seperti pada indikator instrumen konsteks kurikulum MKK PBI bermuatan karakter bangsa disajikan pada Tabel 11.

Tabel 11. Harga Std. Error Means (SEM) instrumen konteks kurikulum MKKPBIKB

\begin{tabular}{lcccc}
\hline Indikator & $\mathrm{N}$ & Mean & SD & SER \\
\hline TUJ & 311 & 24,86 & 7,121 & 0,404 \\
RANC & 311 & 18,91 & 4,767 & 0,270 \\
NILAI & 311 & 12,24 & 3,285 & 0,186 \\
LEMB & 311 & 7,23 & 1,822 & 0,103 \\
\hline
\end{tabular}

Tabel 12. Interval Nilai Tengah untuk Kategori Sedang Instrumen Evaluasi Konteks KurMKKPBIKB

\begin{tabular}{lc}
\hline \multicolumn{1}{c}{ Indikator } & Kategori Sedang \\
\hline Tujuan Pembelajaran & $23 \leq \mathrm{X} \leq 25$ \\
Rancangan Silabus & $17 \leq \mathrm{X} \leq 19$ \\
Penilaian Kelas & $11.6 \leq \mathrm{X} \leq 12$ \\
Kelembagaan & $6,7 \leq \mathrm{X} \leq 7$ \\
\hline
\end{tabular}

Dengan menggunakan rumusan internal dan harga SER pada Tabel 11 dan dengan melihat harga pada tabel Deviasi Normal (ukuran sampel melebihi 100) sebesar 1,960 diperoleh interval nilai tengah untuk kategori sedang pada instrumen konteks KurMKKPBIKB seperti disajikan pada Tabel 12.

Dengan demikian, diperoleh norma kategorisasi untuk tiap indikator instrumen konteks kurikulum MKKPBIKB disajikan pada Tabel 13.

Tabel 13. Norma Kategorisasi Instrumen Evaluasi Konteks KurMKKPBIKB

\begin{tabular}{lcc}
\hline \multicolumn{1}{c}{ Indikator } & $\begin{array}{c}\text { Norma } \\
\text { Kategorisasi }\end{array}$ & Kategori \\
\hline Tujuan Pemb & $\mathrm{X}<23$ & Rendah \\
& $23 \leq \mathrm{X} \leq 25$ & Sedang \\
Rancangan & $25<\mathrm{X}$ & Tinggi \\
Silabus & $\mathrm{X}<17$ & Rendah \\
& $17 \leq \mathrm{X} \leq 19$ & Sedang \\
Penilaian Kelas & $19<\mathrm{X}$ & Tinggi \\
& $\mathrm{X}<11,6$ & Rendah \\
& $11,6 \leq \mathrm{X} \leq 12$ & Sedang \\
Kelembagaan & $\mathrm{X}<\mathrm{X}$ & Tinggi \\
& $6,7 \leq \mathrm{X} \leq 7$ & Rendah \\
& $7<\mathrm{X}$ & Sedang \\
& & Tinggi \\
\hline
\end{tabular}

Hasil evaluasi reflektif kurikulum rumpun MKK PBI secara keseluruhan dinilai menggunakan kriteria umum penilaian berdasarkan persentase untuk membedakan muatan KB pada kurikulum seperti berikut:

Tabel 14. Kriteria Umum Penilaian Muatan Karakter Bangsa pada KurMKKPBIKB

\begin{tabular}{ccc}
\hline KRITERIA & Penilaian & KET \\
\hline $76-100 \%$ & SK & Sangat Kuat Muatan KB \\
$51-75 \%$ & K & Kuat Muatan KB \\
$26-50 \%$ & L & Lemah Muatan KB \\
$0-25 \%$ & SL & Sangat Lemah Muatan KB \\
\hline
\end{tabular}

\section{Simpulan dan Saran}

Hasil penelitian dan pembahasan terhadap model evaluasi reflektif kurikulum rumpun MKK PBI dalam pengembangan karakter bangsa dapat disimpulkan: (1) model ini mencakup lima konstruk dan lima in- 
strumen evaluasi reflektif kurikulum bermuatan karakter bangsa yang mencakup dimensi konteks kurikulum, dimensi pengetahuan, dimensi bahan ajar, dimensi proses pembelajaran, dan dimensi produk pembelajaran afeksi (karakter bangsa mahasiswa). Model pengukuran kurikulum bermuatan karakter bangsa yang disusun berdasarkan konstruk kurikulum bermuatan karakter bangsa fit (cocok) dengan model, yang berarti didukung data empirik dengan nilai GFI sebesar 0,99 sesuai kriteria mendekati 1 atau $\geq 0,98$ dan nilai SRMR sebesar 0,06 sesuai kriteria mendekati 0 atau $\leq 0,08$; (2) Semua instrumen evaluasi reflektif kurikulum MKK PBI dalam pengembangan karakter bangsa telah teruji validitas dan reliabilitasnya, yaitu memiliki muatan faktor $>0,50$ dan reliabilitas paling kecil 0,70 dengan rincian sebagai berikut: instrumen evaluasi muatan karakter bangsa dalam konteks kurikulum berjumlah 20 butir memiliki muatan faktor $>0,50$ dan reliabilitas sebesar $0,92 \geq 0,70$; Instrumen evaluasi pengetahuan dosen tentang pendidikan karakter berjumlah 17 butir memiliki muatan faktor $>0,50$ dan reliabilitas sebesar $0,90 \geq 0,70$; Instrumen evaluasi muatan karakter bangsa dalam bahan ajar berjumlah 17 memiliki muatan faktor $>0,50$ dan reliabilitas sebesar $0,94 \geq 0,70$; Instrumen evaluasi muatan karakter bangsa dalam proses pembelajaran berjumlah 25 butir memiliki muatan faktor $>0,50$ dan reliabilitas sebesar $0,95 \geq 0,70$; dan Instrumen evaluasi produk pembelajaran afeksi (karakter bangsa mahasiswa) berjumlah 21 butir memiliki muatan faktor $>0,50$ dan reliabilitas sebesar $0,83 \geq$ 0,70 ; (3) hasil pengembangan model evaluasi reflektif kurikulum MKK PBI dalam pengembangan karakter bangsa yang telah dibangun berdasarkan kajian pustaka, penilaian rekan sejawat, pakar, dan praktisi, dan uji coba empirik terdiri atas lima aspek/dimensi evaluasi dengan nama Konteks (Context), Pengetahuan Dosen (Input), Bahan Ajar (In$p u t)$, Proses (Process), dan Produk (Product) yang dapat disingkat menjadi CIIPP (Context-Input-Input-Process-Product). Model evaluasi yang dikembangkan ini terdiri dari seperangkat instrumen evaluasi, skema model evaluasi, panduan cara melakukan kegiatan evaluasi dan kriteria penyekorannya yang dapat digunakan untuk memfasilitasi proses refleksi diri dosen terhadap kurikulum MKK yang diselenggarakannya, karena memiliki model pengukuran yang fit (cocok) dengan model yang didukung data empirik dengan nilai GFI sebesar 0,99 sesuai kriteria mendekati 1 atau $\geq 0,98$ dan nilai SRMR sebesar 0,06 sesuai kriteria mendekati 0 atau $\leq 0,08$.

Beberapa saran pemanfaatan produk evaluasi reflektif kurikulum rumpun MKK PBI adalah sebagai berikut: (1) model dapat dipergunakan oleh para dosen sebagai refleksi diri terhadap penuangan muatan karakter bangsa dalam kurikulum MKK yang diselenggarakannya demi mem mempersiapkan calon guru bahasa Inggris yang tidak hanya kompeten dan professional tetapi juga mempunyai kesadaran untuk membentuk karakter bangsa peserta didiknya kelak; (2) Ketua Program Studi dapat memanfaatkan hasil evaluasi sebagai dasar untuk merencanakan kegiatan internal yang dapat membantu mengingatkan dan memastikan penuangan karakter bangsa dalam kurikulum pembelajaran yang diselenggarakan oleh tiap dosen secara rutin dan berkesinambungan seperti yang diamanatkan oleh UUD dan demi mewujudkan visi dan misi lembaga; (3) pimpinan perguruan tinggi dapat memanfaatkan hasil evaluasi untuk pengambilan keputusan terkait langkah-langkah yang harus dilakukan dalam memastikan penuangan karakter bangsa dalam mempersiapkan lulusan yang memiliki selain kompetensi dan profesionalisme juga kesadaran dan karakter bangsa yang kuat dalam membangun bangsa dan Negara.

\section{Daftar Pustaka}

Apple, M.W. \& Beyer, L.E. (1983). Social evaluation of curriculum. American Educational Research Association, 5 (4), 425-434.

Azwar, S. (2012). Penyusunan skala psikologis, Edisi 2. Yogyakarta: PUSTAKA PELAJAR. 
Bath, D. Smith, C. Stein, S. \& Swann, R. (2004). Beyond mapping and embedding graduate attributes: bringing together quality assurancae and action learning to create a validated and living curriculum. Higher Education Research \& Development, 23 (3), 313 . 328.

Beane, J.A. Toepfer, C.F. Jr. \& Alessi, S.j. (2004). Curriculum planning and development Boston: Allyn and Bacon, Inc.

Berkowitz, M. W., \& Bier, M.C. (2004). Research-based character education. The ANNALS of the American Academy of Political and Social Science, 591 (1), 7285.

Cennamo, K. \& Kalk, D. (2005). Real world instructional design. Canada: Thomson Wadsworth.

Davis, E. (1980). Teachers as curriculum evaluatiors. North Sydney: GEORGE ALLEN \& UNWIN.

Hamilton, D. (1977). Making sense of curriculum evaluation: continuities and discontinuities in an educational ideas. Review of Research in Education, 5, 318-347.

Heungsun Hwang. (2011). GeSCA user's manual. Diakses tanggal 15 Juni 2013 dari www.sem-gesca.org

Jackson, P.W. (Ed.).(1992). Handbook of research on curriculum: a project of the American Educational Research Association. New York: MACMILLAN PUBLISHING COMPANY.

Kementerian Pendidikan Nasional Badan Penelitian dan Pengembangan Pusat Kurikulum. (2010). Bahan pelatiban penguatan metodologi pembelajaran berdasarkan nilai-nilai budaya untuk membentuk daya saing dan karakter bangsa: pengembangan pendidikan budaya dan karakter. Diakses tanggal 27 April 2011 dari bttp:// www.puskur.net/files/1 \%20Pendi dikan $\% 20$ Budaya\%20dan $\% 20$ Karakter $\%$ 20Bangsa.pdf
Ketetapan MPR RI No. VII/MPR/1978.

Ki Hadjar Dewantara. (2004). Karya Ki Hadjar Dewantara bagian pertama: pendidikan. Yogyakarta: Majelis Luhur Persatuan Taman Siswa.

Lawshe, C.H. (1975). A quantitative approach to content validity. Personnel Psychology, 28, 563-575.

Leming, J.S. (2000). Tell me a story: an evaluation of literature-based character education program. Journal of Moral Education, 29 (4), 413-426.

Marsh, C. J. (2009). Key concepts for understanding curriculum. London: Routledge.

Martone, A. \& Sireci, S.G. (2009). Evaluating alignment between curriculum, assessment, and instruction. Review of Educational Research, 79, 13321361.

Meadows, B. (2008). Co-constructing the 'Familiar Exotic' in second language learner discourse. Texas Linguistic Forus, 52, 117-130.

Narvaez, D., \& Lapsley, D.K. (2006). Teaching moral character: two strategis for teacher education. In Press,

Nunan. (2004). Task-based language teaching. Cambridge: Cambridge Language Teaching Library

Orstein, A.C. \& Hunkins, F.P. (2009). Curriculum: foundations, principles, and issues. ( $5^{\text {th }}$ ed.) Boston, MA: Pearson International Edition.

Parkay, F.W., Hass, G.J., \& Anctil, E.J. (2010). Curriculum leadership: readings for developing quality educational programs. PEARSON.

Parmenter, L. (1999). Constructing national identity in a changing world: perspective in Japanese education. British Journal of Sociology of Education, 20 (4), 453-463.

Pemerintah Republik Indonesia. (2010). Kebijakan nasional pembangunan karakter bangsa tabun 2010-2025. Diakses 
tanggal 11 Pebruari 2013 dari http:// www.google.com $/ \#$ hl=en\&tbo $=\mathrm{d} \& \mathrm{o}$ utput $=$ search\&sclient $=$ psyab\&q=kebijakan + nasional + pembang unan+karakter+bangsa + tahun $+2010-2025 \& g s$

Richards, J. C. (2001). Curriculum development in language teaching. New York: Cambridge Language Education.

Ringle, C.M. Wende, S. \& Will, S. (2005). SmartPLS 2.0 (M3). Beta, Hamburg. Diakses tanggal 10 Juli 2013 dari http://www.smartpls.de

Saifuddin, A.F., \& Karim, M. (2008). Refleksi karakter bangsa. Jakarta: Penerbit Forum Kajian Antropologi Indonesia.

Sari, M, \& Doğanay, A. (2009). Hidden curriculum on gaining the value of respect for human dignity: a qualitative study in two elementary schools in Adana. Educational Sciences: Theory \& Practice, 9 (2), 925-940.
Sumarno. (2011). Peran pendidikan nonformal dan informal dalam pendidikan karakter bangsa. Cakrawala Pendidikan Jurnal Ilmiah Pendidikan, Mei, Th. XXX, Edisi Khusus Dies Natalis UNY, 73-84.

Taylor-Powell, E., Jones, L., \& Henert, E. (2003). Enhancing program performance with logic models. Diakses tanggal 1 Maret 2011 dari http://www.uwex. edu/ces/Imcourse/

Winarno. (2010). Implementasi Pancasila melalui pendidikan kewarganegaraan (civic education). Makalah disajikan dalam Seminar Pengalaman Indonesia dan Malaysia dalam hal pembinaan warga Negara yang cerdas dan baik, di Universitas Pendidikan Sultan Idris.

Worthen, B.R., \& Sanders, J.R. (1984). Educational evaluation: theory and practice. Worthington, OH: Charles A Jones Publishing Company.

Undang-Undang RI Nomor 20, Tabun 2003, tentang Sistem Pendidikan Nasional. 